\title{
Changes and Challenges of Modern Society: what it Takes to Reach a Near-Native Level of Foreign Language Proficiency
}

\author{
Elena B. Grishaeva* \\ Siberian Federal University \\ 79 Svobodny, Krasnoyarsk, 660041, Russia
}

Received 12.09.2015, received in revised form 10.10.2015, accepted 28.10.2015

\begin{abstract}
The article presents a controversial nature of undergoing radical changes in the sphere of teaching / learning foreign languages at the University level. Modernization of higher education in Russia requires critical understanding of efficient teaching methodology of English for Specific Purposes $(E S P)$. Historical perspective highlights language policy issues; describes efficacy and efficiency of the communicative approach in teaching / learning languages; shows multiple collisions of socio-cultural vs political issues in language education, and tackles desiderata of lifelong learning (LLL): continuing education for teachers of foreign languages. Diachronic insight into educational paradigms and description of the communicative approach via functional and contrastive methods make possible elaborating and formulating a series of principle assumptions, which are of utmost significance for the universities of the Russian Federation.
\end{abstract}

Keywords: English for Specific Purposes, language policy, language management, communicative approach.

The article is written with the financial support of the European Commission within the Tempus IV programme (Project "Lifelong Language Learning University Centre Network for New Career Opportunities and Personal Development (UNICO)”, № 544283-TEMPUS-1-2013-1-ES-TEMPUSJPHES).

DOI: 10.17516/1997-1370-2015-8-11-2331-2340.

Research area: pedagogy, philology.

\section{Introduction}

Despite modernization, that currently takes place in the Russian Federation, language policy in the sphere of higher education is unlikely balanced on the state level. Teaching / learning a professionally oriented and academic English as one of the major subjects is dramatically controversial. State regulations and authoritative solutions do not match neither students' nor teachers' expectations. Various social and political parameters, motives and interests turn, on the one hand, to confront each other, and on the other hand, make a negative impact on the spread of English for academic and specific purposes.

Nowadays English is often seen as a modern trend and as a major means of instruction. Moreover, in a strict accordance with modern rhetoric, English is a prerequisite and a

(C) Siberian Federal University. All rights reserved

* Corresponding author E-mail address: e-grishaeva@mail.ru, elena.grishaeva2@mail.ru 
practical competence of university graduates for further employment and maintenance of their competitiveness and potential on the market of labour force.

As far as linguists, political scientists, sociolinguists and teachers deal mainly with languages and the ways they relate to their users, whether as individuals or in communities, we cannot avoid addressing to language policy and planning as a social phenomenon. Language policy is interpreted as a combination of measures taken by institutionalized structures to introduce the new or save the current functional distribution of languages in this or that sphere of social life. Sociolinguists claim that language policy mobilizes both material and symbolic resources, and, thus, cause direct economic consequences. Since 1980-s, sociologists of language have got interested in the nature of a closer link between language and economy of education. Language skills were considered as a certain capital and as a resource of economic advantage that determined the amount of personal income. In other words, the language issues referring to a status language are the core elements of economic approach. As it is widely known, the state influences on the functional status of languages via various channels, such as administrative and legal systems, state financing, general and higher education. In order to manifest a relative value of different language environments, they refer to the so - called "fundamental rule of the political choice", i.e. the choice made in favour of the most evident advantage. In this particular context for net profit, which can be formulated as "profit minus expenditures" (Stokey \& Zeckhauser, 1978: 34).

The end of the 20-th century was marked in the European Union by transitioning in the sphere of education from the monolingual model to the multilingual format of communication. Under the scheme in question, collocutors change linguistic codes and automatically switch from one language to another irrelevantly whether they can speak the language fluently or just have a limited repertoire of linguistic skills. Thus, from the sociolinguistic standpoint, the EU had formulated universal aim to attain individual competence in three languages: native tongue, regional language or English.

Modern Europe strongly advocates a combination of the "elite plurilinguism" and so called "consumerist English". This mix assumes active knowledge of one or two languages along passive knowledge of English, mobile and limited, necessary for consumerist purposes (Graddol, 1997).

It is a well-known fact that due to spread of the world English, educational options in some South-Eastern Asian countries were restrained by political aims. English as a second language made possible interlingual communication. English had easily integrated into educational and social systems of various Asian countries. Along with cultivated autochthonous vernaculars, English is currently seen as a "second mother tongue", which cohabits with the other ones, and simultaneously, dominates over them (Pool \& Fettes, 1998: 2).

$\mathrm{Mr}$ N. Nazarbayev, the President of Kazakhstan, referring to the system of education in Malaysia and Singapore, has recently claimed that some subjects at the secondary level should be taught in English. "We need to start learning English from the grade one. In grades 11 and 12 of the secondary schools all the subjects should be taught in English. In other words, younger generations have to study in three languages: Kazakh, Russian and English" (http://www. kaztag.kz/en/news/detail.php?ID=349622).

If to look at the languages from the point of view of matching to behavioural patterns, one can argue that so called "functional multilinguism" is spreading all over the globe. The use of languages depends on their relative utility and on 
the choice of speakers. Functional diversity either of languages getting wider, or, on the contrary, shrinks. Modern economic and technological context requires cultivating of a global language as a means of interethnic communication. Only internationalized English, a lingua franca under globalization, celebrates nowadays this role. In other words, those people who want to integrate into a global level of communication should necessarily become bilinguals. The only option is available: the spread of such ecology of language under which either individual bilingualism or "elite polylinguism" are maintained.

\section{Problem Statement}

In the logic of the above-mentioned approach and in order to provide linguistic freedom in the dynamically developing world, it is the time to modernize educational sphere, to introduce into it new initiatives on learning and teaching foreign languages. National educational policy should encourage a wider access to the world values and knowledge at the level of the world standards, as well as to enhance social mobility.

Language management (different means of adequate and efficient language teaching; integration of the population into civilized institutions and a high caliber and qualification human resources development), come into play on the front stage, including a local level. In the context of further development of the global culture, the linguistic aims of the flagship universities should be the following ones: getting aware of language diversification; recognition of direct communication via lingua franca (the world English); adequate understanding of the fact that under market economy students purchase educational products. This is their intrinsic right, covered by legal system; modern high school in the Russian Federation should survive via transitioning onto diversification of the educational content and university curriculum management, which depend on the mission of the university, its aims and objectives and a social order both from regional and world economies.

As M.C. Pennington and H.D. Brown argued, one of the most invigorating things about teaching is that a teacher never stops learning. Every time s/he walks into a classroom to teach Business English, for instance, s/he faces an endless number of questions to answer, problems to solve, issues to ponder. If $\mathrm{s} / \mathrm{he}$ is a growing teacher, s/he learns something. Teachers "find out how well a technique works, how a student processes language, how classroom interaction can be improved, how to assess a student's competence, how emotions enter into learning, or how teaching style affects learners. The discoveries go on and on - for a lifetime.

As you embark on this journey into the teaching profession, how can you best continue to grow professionally and how can you most fruitfully meet the challenges that lie ahead? Are there some practical goals that you can pursue?" (Pennington, 1990: 150; Brown, 1994: 425).

Among major professional goals one can tackle are the following ones:

- A knowledge of the theoretical foundations of language learning and teaching;

- An awareness of alternative teaching techniques and the ability to put these into practice;

- The confidence and skill to alter your teaching technique as needed;

- Practical experience with different teaching techniques;

- Interpersonal communication skills;

- Attitude of flexibility and openness to change (Brown, 1994: 426).

These goals can provide a continuing career growth for many years as you strive to a better job of teaching. There is the only precaution: a teacher should not expect to become a "master" teacher overnight. If you try to focus on everything in the 
classroom all at once (all the management issues, techniques, delivery, body language, feedback, individual attention, lesson goals and mid-lesson alterations), you may end up doing nothing well. In due course of time, however, the abundance of cognitive/emotional phenomena in the classroom will be sufficiently automatic (Ibid.: 426).

When answering a sacred question "Are you doing the best you can do?" it is worth reminding the phenomenon of being all that you can be "self-actualized", in Maslow's terms. Therefore, "peak performers", people who are reaching their fullest potential might apply to themselves a set of the following rules:

1. Set realistic goals in what you can accomplish within a framework: limitations and strengths; feelings and needs. If you have a sense of overall purpose in your career as a mission, then this mission will unfold in the form of daily, weekly, monthly, or annual goals.

As scientists argue, teachers should plan to read several teacher resource books this year; use intrinsically motivating techniques; observe five other teachers this semester, or attend two professional conference / workshops this year.

2. Set priorities: It is important that teachers have a sense of what is most important and what is least important, and everything in between, in their professional goals and tasks. Priority setting requires a sense of their whole life, professional and personal.

3. Take risks: peak performers are not afraid to try new things. They do not linger in the safety of a "comfort zone"; instead, they reach out for new challenges. The key to risk taking as a strategy is in learning from "failures". When you risk a new technique in the classroom, or a frank comment to a supervisor, you must be willing to accept the possible "failure" in your attempt.

4. Practice principles of stress management. Teaching is a career with all the marking for high stress conditions: long hours, large classes, low pay, high student expectations, emotional connections with students' lives, bureaucracies, pressure to keep up with a rapidly changing field, information overload. Managing those potential stress factors is an important key to keeping yourself fresh, creative, bright, and happy" (adapted from Brown, 1994: 427-428).

\section{Discussion}

To begin setting goals and priorities is to consider the qualities of successful language teachers. I am personally sympathizing with a once offered by Harold B. Allen "down-to-earth" list of characteristics of good ESL teachers:

- Competent preparation.

- A love of the English language.

- The critical faculty.

- The resistant urge to upgrade oneself

- Self-subordination

- Readiness to go the extra mile

- Cultural adaptability.

- Professional citizenship.

- A feeling of excitement about one's work (Allen, 1980).

How would we rate ourselves on all the above items? Is there any room for improvement on any of them?

According to H.D. Brown, one of the most neglected areas of professional growth among teachers is the mutual exchange of classroom observations. Teachers should come to understand that seeing one's actions through another's eye is an indispensable tool for classroom research as well as potentially enlightening for both observer and observee. Via visiting other teachers and inviting reciprocity, you will gain new ideas, keep fresh, and sharpen your own skills (Brown, 1994: 431).

Let us not to forget another form of observation - a self-observation. It is the systematic part that is crucial in monitoring yourself. It requires discipline and perseverance, but the results are worth it. 
1. Select an element (like teacher talk, eye contact, teaching predominately to one side of the classroom, or whiteboard work) of your teaching to "keep an eye out for".

2. Monitor that particular element during the class period.

3. Set aside a few moments to give these elements careful assessment (Ibid.: 431).

Alastair Pennycook's statement, taken from his very stimulating essay on language teaching, power and politics has stunned me very much. According to him, teachers are "transformative intellectuals" who must see themselves 'as professionals who are able and willing to connect pedagogical theory and practice to wider social issues, and who work together to share ideas, exercise power of the conditions of our labour, and embody in our teaching a vision of a better and more human life" (Pennycook, 1989: 613).

Another deep insightful statement draws attention: "Teaching is a political act". It means that you have a set of beliefs about how the people of this world should behave toward one another. You have convictions about the quality of life, the shape of liberty, and the pursuit of happiness. You are engaged in a political, empowering act when you teach English. You will no doubt be very careful not to push a particular "philosophy" or morality onyourstudents, butyou will nevertheless be acting from your deepest convictions when you teach people to speak tactfully, to negotiate meaning harmoniously, to read critically, and to write persuasively.

You are not merely a language teacher; you are an agent for change: change from competition to cooperation, from powerlessness to empowerment, from conflict to resolution, from prejudice to understanding (Brown, 1994: 441-442).

You also will need to develop a lifelonglearning approach to foreign language acquisition to acquire professional and advanced professional (near-native) levels of foreign language proficiency. There is not a lot known about how to do this.

Pragmatically oriented consumerist concept of higher education matches interests of business circles, which integrated universities into a "free economy market". Universities of innovative type are puzzled with language issues, namely, they try to figure out what language policy to implement in order to gain efficient results; how to explain success of one group of students acquiring English and failure of another one; why some language programmes are better than the other ones.

A concept of deroutinization of teaching a professionally oriented English makes sense for advanced and challenged teachers nowadays. They visualize it as a basic principle in shaping educational content and adopting learning material to the needs of communication. The core elements of the learning paradigm is defining the aims and further translating them into a set of objectives.

Teachers should take into consideration that the defined aim and objectives are to meet requirements, as follows:

- They must be clearly formulated

- They must be put into practice

- They must suit the level of students

- They must be checked and tested.

Moreover, today we have to realize and answer with any certainty the questions that lie at the very foundations of language teaching: who should learn a foreign language, why learners learn, what they need to learn, and what we want to teach them - answers that we need before we can consider how we want to teach. All the stakeholders of the teaching / learning process encounter various challenges categorized as technical, financial and social.

It is worth reminding Ferdinand Brunot, a French linguist, an author of the "History of the 
French Language" who emphasized the links of the national literary language with political, social and cultural development of the country. He also introduced a three-component approach (HoLLT history of language learning and teaching): sociocultural, pedagogical and linguistic. Of these three strands, it is the first that is most prominent (Mc Lelland \& Smith, 2014: 5).

English entered the Russian educational field later than French or German. English is central nowadays in the curricula not only of the high school, but of the secondary school as well. Taking into consideration methodology of language teaching in this country in a historical perspective, one should argue that there is no any other alternative to the so-called communicative approach neither in terms of emotional nor impressionistic perception. Speaking didactically, for more than 25 years a communicative approach had a purpose - to develop of communicative competence, i.e. ability to use language in the situation-induced context (Hymes, 1972; Klimova, 2014). Situation is a means of discourse stimulation, which improves discursive skill. In other words, this statement means attaining knowledge-based competence in languages - phonetical, grammatical, semantic, stylistic and syntactical. There is one more basic principle, which is connected with novelty that helps develop ability to paraphrase, to build a mechanism for linguistic combinations, to initiate utterances, to use a particular tempo of discourse, and especially - a speaker's strategy and tactic (Лемайкина; Пузаков, 2004: 81).

However, one can face a multitude of views in current specialized literature, which evidence a post-communicative approach to English language teaching (Klimova, 2014: 85). Scholars claim that communicative approach should not be overestimated in terms of its importance and results. In other words, it needs reconsideration. Linguists and teachers think currently about attaining a balance between conscious learning and teaching besides its unconscious acquisition. They claim that attention should be paid to accuracy, not only to speech fluency. They also emphasize the role of teacher in this educational process. They support the integration of all four-language skills, not only speaking. They stress knowledge of a foreign language, not only its communicative competence. What is more important, they understand language as an expression of social identity of a person, not only as a means of communication (Ibid.: 86).

Historiography of the communicative competence defined the following competences: linguistic, pragmatic, intercultural, strategic and discourse (Klimova, 2014: 86-87).

The linguistic competence involves knowledge of spelling, pronunciation, vocabulary, word formation, grammatical structure, sentence structure, and linguistic competence. It is important to stress that the linguistic competence plays a crucial role in communicative competence because it is impossible to conceive of a person being communicatively competent without being linguistically competent. If teachers start with communicative competence too early, without considering language accuracy, students can permanently fix serious language errors.

The pragmatic competence comprises two abilities: illocutionary competence (knowing how to use language when achieving certain goals in communication) and sociolinguistic competence (knowing what language to use in different setting or with different people).

The intercultural competence involves knowledge of intercultural conditions of language use such as courtesies and other rules.

The strategic competence is defined as the ability to cope in an authentic communicative situation, i.e. to be able to express oneself although there is a lack of the resources to do so successfully. 
The discourse competence is the centre of all competences. Moreover, the other competences are carried out in it with the help of four language skills.

The language skills are both the aim (they are used in everyday communicative situations) and the means for the implementation of the communicative goal (they are used in the activities aimed at the acquisition of language means: vocabulary, grammar, pronunciation etc).

The language skills are traditionally divided into receptive (listening and reading) and productive (speaking and writing). According to the format of the communicative process, they are spoken and written. The aim of ELT is to use these skills in their integration. Research studies show that the productive language skills are developed least in ELT. The reasons for a lack of the development of the productive language skills are as follows:

- Teachers do not use the target language fully.

- Teachers do not integrate all four-language skills.

- Teachers pay little attention to the development of language functions.

- Teachers do not develop student's learning strategies.

- Students' negative approach to the target language; low motivation (Klimova, 2014: 88).

As we all understand, there is only one prerequisite leading to a complete change of increasing productive skills. As far as the methods are concerned, the most common is a method of practical activities: a method of drawing and conversation, a method of singing and reciting. There are many professionals advocating this method to be used in the kindergartens and pre-school classes. However, I personally do not believe in this method. Language should be a terrain for senses and meanings. Although controlled speaking, guided speaking and free speaking are systematically taught at school, students' proficiency level is far from desired.

What we do at the university level, we use the so-called method of task-based learning (TBLL), a stronger version of the communicative approach, which is supposed to enable students to solve real-world issues. There is a set of stages: pre-task activity, task, planning, report, analysis, and practice (Richards \& Rodgers, 1986/2001). Practitioners, on the one hand, assess this method as having indisputable advantages (students can cooperate in groups, develop cooperative learning: prepare joint presentations, develop metacognitive skills such as the skills of critical thinking and reflection).

On the other hand, TBLL lacks in sensitivity to the social and cultural dimensions of language learning (Ortega, 2007; Klimova, 2014: 89). Furthermore, the naturalistic bias of TBLL has been deemed efficient for teaching basic grammar and vocabulary for the beginning level (Swan, 2005).

Thus, the successful mastering of speaking can be achieved if:

- Teacher / learner use consolidated language means;

- teacher develop speaking skills every single lesson;

- teacher gives comprehensible instructions;

- teacher makes students speak the target language, providing balanced conditions to use four language skills.

The key role is undoubtedly taken by motivation (i.e. a desire to invest one's effort into learning). The following factors influence intrinsic motivation:

- Physical conditions, in which the target language is taught;

- Teaching methods; 
- Personality of the teacher in creating pleasant atmosphere and good rapport with students;

- Success in completing the task.

Among the strategies for the development and sustainability of motivation, scholars stipulate the following ones: to increase the attractiveness of the task, which makes learning stimulating and enjoyable and to support student confidence (Dornyei, 2001).

In addition, the teaching by CLIL (Content and Language Integrated Learning) can also be a solution at the university level.

Finally, it is the personality of ELT teacher, his qualification, expertise, enthusiasm and willingness to further educate in the field of ELT and develop a lifelong-learning approach to foreign language acquisition to acquire professional and advanced professional (nearnative) levels of foreign language proficiency. To date, there is not a lot known about how to do it.

Study abroad phenomenon also can be a little surprising; many students evidence that study abroad helps them at intermediate levels, but not at high level. This is always a combination of incountry experience and classroom instruction that made a difference.

The kinds of activities that typical successful high-level language learners have practiced include:

- Assessments

- Individualized study plan

- High-level courses

- Cross-cultural observation

- Sociolinguistic sophistication

- Contact with native speakers

- Time on task

- Formal language use (Leaver, Ehrman, Shekhtman, 2005: 238).

Periodic assessments help learners stay on track and to measure progress. Everyone should keep in mind that the higher your proficiency, the slower will be your overt progress, i.e. the nexthigher proficiency level will take longer to reach. There is a learning curve that flattens out at the higher levels because there is so much to know by the time you start approaching near native levels of speech.

One of the main hallmarks of very high-level language is its precision. The speaker uses just the right synonym, construction, or idiom, rather than relying on the ability of the interlocutor to understand from context what is really meant by a less precise term.

The more time you spend reading, speaking, writing in a foreign language, the better you will be at it, regardless of whether you learn quickly or with difficulty. Language proficiency takes time to hold.

As the scholars claimed, finding every possible opportunity to develop and use formal language can be critical to the development of high-level skills. "The subtleties of formal language that are needed for writing for publication, editing, negotiating effectively, truly controlling the conversational partner, adapting speech and writing to the audience. These are often skills that not even every native speaker has; they are the skills that are generally developed by native speakers and foreign-language learners, as a result of experience and meeting the linguistic requirements of higher education' (Leaver, Ehrman, Shekhtman, 2005: 242).

\section{Conclusion}

Shaping the direction of language teaching and learning in the Russian universities, we used diachronic analysis of dominant concepts and procedures in the field of learning and acquisition of foreign languages. As we have featured, the picture is full of eclectic approaches towards multifaceted teaching / learning practices. In stark contrast to the statement that only communicative method brings results, the majority of individuals, 
as it was shown in the recent studies, learnt from either grammar-based or audiolingual methods (Leaver and Atwell, 2002: 236).

Moreover, other lingua-didactic methods, such as the Grammar-Translation Method / the Direct Method also have been working efficiently in different periods. We are sharing arguments of B. Hunter and R. Smith who claimed that there is a tendency to assign method labels to bounded periods of history of teacher training and a foreign language learning in many countries. Teachers should realize that communicative approach does not address strict prescription. Due to its "over-methodization", communicative approach is worth being unpackaged and got free from over-static, oversimplified notions. All didactic methods and approaches should be reconsidered as being a "store house" or "treasure chest" of history, "removing the labels on method packages and unbundling them, all in the service of recovering the professional past and recycling it as a complex and usable resource for the present" (Hunter and Smith, 2012: 430).

\section{References}

Allen, H. What it means to be a professional in TESOL. Lecture presented at the conference of TEXTESOL, April 1980.

Brown, H.D. Teaching by Principles: an Interactive Approach to Language Pedagogy. Prentice Hall Regents, 1994. 467 p.

Dornyei, Z. Motivational strategies in the language classroom. Cambridge, CUP, 2001.

Graddol, D. The Future of English. London, the British Council, 1997.

Grishaeva, E.B. (2015). Communicative Approach in a Diachronical Perspective: Pro and Contra. International Journal of Applied and Fundamental Research, 5 (Part 4), 582-586.

Hunter, D. \& Smith, R. (2012). Unpackaging the past: 'CLT' through ELTJ keywords. ELT Journal, 66(4), 430-439, doi: 10.1093/elt/ccs036.

Hymes, S. On communicative competence. J.B. Pride, \& J. Holmes (eds.), Sociolinguistics. Harmondsworth, Penguin, 1972.

Klimova, B.F. (2014). Detecting the development of language skills in current English language teaching in the Czech Republic. Elsevier: Procedia - Social and Behavioral Sciences, 158, 85-92.

Leaver, B.L. and Atwell, S. Preliminary qualitative findings from a study of the processes leading to advanced professional proficiency level (ILR 4). B.L. Leaver and B. Shekhtman (eds.), Developing professional-level language proficiency. Cambridge: Cambridge University Press, 2002, pp.260-279.

Leaver, B.L., Ehrman, M., \& Shekhtman, B. Achieving Success in Second Language Acquisition. Cambridge: Cambridge University Press, 2005, 265 p.

Lemaikina, L.M.; Puzakov, A.V. (2004). Teaching methods of the foreign languages for the university students (majoring in Psychology). Scientific Journal of Mordovia University, 1(2), 80-82.

McLelland, N. \& Smith, R. (2014). Introduction: Building the History of language Learning and Teaching (HoLLT). Language and History, 57(1), 1-9.

Ortega, L (2007). Participation, acquisition, and in-betweenness as metaphors for L2 learning. Plenary address delivered at the $1^{\text {st }}$ Combined ALANZ-ALLAA Conference [Applied Linguistics Association of New Zealand \& Applied Linguistics Association of Australia], Auckland, December $2-4$. 
Pennington, M.C. A Professional development focus for the language teaching practicum. J. C. Richards and D. Nunnan, (eds.). Second Language Teacher Education. Cambridge University Press, 1990.

Pennycook, A. (1989). The concept of method, interested knowledge, and the politics of language teaching. TESOL Quarterly, 23 (4), 589-618.

Pool, J. \& Fettes, M. (1998). The Challenge of Interlinguisme: A Research invitation. Esperantic Studies, 10, 1-3.

Richards, J.C. \& Rodgers, T.S. Approaches and Methods in Language Teaching (second edition). Cambridge University Press, 2001.

Stockey, E. \& Zeckhauser, R.A. A Primer for Policy Analysis. New York, Norton, 1978.

Subjects must be taught in English for secondary schools' pupils - Nazarbayev (06.03.2015), Available at: http://www.kaztag.kz/en/news/detail.php?ID=349622 (accessed 1 November 2015).

Swan, M. (2005). Legislation by hypothesis: the case of task-based instruction. Applied Linguistics, 26, 376-401.

\title{
Изменения и вызовы современного общества: \\ способы достижения профессионального уровня
}

владения иностранным языком

\author{
Е.Б. Гришаева \\ Сибирский федеральный университет \\ Россия, 660041, Красноярск, пр. Свободный, 79
}

Статья отражает опыт исследования функционального аспекта языковой политики в сфере высшего образования с помощью системно-функиионального и сопоставительного методов, а также рассматривает в исторической перспективе коммуникативный подход. Критическое осмысление приемов, используемых в лингводидактической деятельности отечественных и зарубежных специалистов, имеет безусловную актуальность для выбора эффективных методов обучения иностранному языку в условиях модернизачии российского высшего образования. Учет исторического развития образовательных парадигм систем лингвистического образования позволяет сформулировать ряд принципиальных положений, необходимых для реализачии программ преподавания профессионально-ориентированного английского языка и английского языка для академических иелей в университетах Российской Федерачии.

Ключевые слова: английский язык для специальных иелей, языковая политика, языковой менеджмент, коммуникативный подход.

Статья написана при финансовой поддержке гранта программы ТЕМПУС IV Европейского Союза (проект «Создание сети университетских языковых иентров для профессионального и личностного развития человека в рамках парадигмы «образование в течение всей жизни», № 544283-TEMPUS-1-2013-1-ES-TEMPUS-JPHES).

Научная специальность: 13.00.00 - педагогические науки, 10.00.00 - филологические науки. 